\title{
A dream that came true: Poland's first successful CAR-T cell therapy in child with refractory B-cell acute lymphoblastic leukemia (ALL)
}

\author{
Paweł Marschollek ${ }^{1 \#}$, Karolina Liszka ${ }^{1 \# \star}$, Ewa Gorczyńska ${ }^{1}$, Monika Mielcarek-Siedziuk ${ }^{1}$, \\ Blanka Rybka ${ }^{1}$, Joanna Taha ${ }^{2}$, Krzysztof Kałwak ${ }^{1}$
}

${ }_{1}^{1}$ Department of Pediatric Bone Marrow Transplantation, Oncology, and Hematology, Wroclaw Medical University, Wroclaw, Poland ${ }^{2}$ Department of Pediatrics, Hematology, Oncology and Diabetology, Medical University of Lodz, Poland

${ }^{\#}$ Both authors equally contributed to this work

\section{Introduction}

The most famous 'proof' in favor of CD19-targeted chimeric antigen receptor $\mathrm{T}$ (CAR-T) cell therapy is Emily Whitehead, the first child to have her own immune cells trained to fight cancer. It worked, and Emily has been cancer-free now for more than eight years.

CAR-T cell therapy is a groundbreaking treatment that has launched a new era in the treatment of hematological malignancies.

Safety and efficacy evaluation of tisagenlecleucel $\left(\right.$ Kymriah $\left.^{\circledR}\right)$ in children was conducted in a clinical trial, ELIANA [1] and described in other studies [2, 3].

In 2017, Kymriah $^{\circledR}$ became the first CAR-T cell therapy approved by the US Food and Drug Administration (FDA) for patients aged up to 25 years who suffer from B-cell precursor acute lymphoblastic leukemia that is refractory or in a second or subsequent relapse. In 2018, tisagenlecleucel was also approved by the European Commission.

CAR-T cell technology is an excellent example of cell gene therapy that is highly personalized to target an individual patient's disease [4].

To create CAR-T cells, a patient's own T lymphocytes need ex vivo genetic manipulation. A gene encoding CAR anti-CD19 is introduced into the genome of T cell with the help of lentiviral vectors. After activation and expansion, ready-to-use CAR-T cells are obtained. When infused into the bloodstream, CAR-T cells are able to penetrate tissues, self-activate, amplify, eliminate neoplastic cells, and act long-term.
The first Polish patient was successfully treated with CAR-T cell therapy in November 2019 at the Department of Hematology and Transplantology in Poznan. He was a 24-year-old male with refractory, early relapsed diffuse large B-cell lymphoma (DLBCL) after autologous stem cell transplantation $[5,6]$.

Also in November 2019, our center was approved by Novartis to become the first pediatric certified site for CAR-T cell therapy in Poland. The first implementation was performed in March 2020 in an 11-year-old boy with multiply relapsed acute lymphoblastic leukemia.

Here, we present that patient's clinical history, which eventually led to this innovative therapy.

\section{Patient and procedure}

The boy had been diagnosed with pre-B cell ALL (qualified later as intermediate risk) at the age of four, and he was treated according to the ALL IC BFM 2009 protocol from January 2013 to March 2015. His first relapse was confirmed 12 months after the end of treatment (March 2016; late mixed relapse; bone marrow (BM) and central nervous system (CNS) affected) and managed with the IntRe ALL SR 2010 protocol. Then, in December 2016, a first allogeneic hematopoietic stem cell transplantation from a matched sibling donor was performed. A second relapse was diagnosed 13 months later (January 2018, isolated marrow relapse). Treatment according to the IntRe ALL HR 2010 protocol (induction: HIB with bortezomib) was started, supplemented with immunotherapy - blinatumomab. In April 2018, a second allo-HSCT, HLA-haploidentical (from the patient's

\footnotetext{
*Address for correspondence: Karolina Liszka, Department of Pediatric Bone Marrow Transplantation, Oncology, and Hematology, Wroclaw Medical University, Borowska 213, 50-556 Wroclaw, Poland, e-mail: cuccinna@gmail.com
PTHiT Copyright (c) 2021 The Polish Society of Haematologists and Transfusiologists, Insitute of Haematology and Transfusion Medicine. All rights reserved. articles and share them with others as long as they credit the authors and the publisher, but without permission to change them in any way or use them commercially 
Table I. CD19 ${ }^{+}, \mathrm{CD}^{+}$, white blood cells (WBC), chimeric antigen receptor T (CAR-T) cell counts and minimal residual disease using polymerase chain reaction (MRD-PCR) in patient monitored since Kymriah ${ }^{\circledR}$ infusion (measurements at time of lymphocytes subpopulation assessment)

\begin{tabular}{|c|c|c|c|c|c|c|c|}
\hline Time point & Date & $\begin{array}{c}\text { CD19 } \\
\text { [cells } / \mu \mathrm{L}]\end{array}$ & $\begin{array}{c}\text { CD3 } \\
\text { [cells } / \mu \mathrm{L}]\end{array}$ & $\begin{array}{c}\text { WBC } \\
\text { [cells } / \mu \mathrm{L}]\end{array}$ & $\begin{array}{c}\text { ANC } \\
\text { [cells } / \mu \mathrm{L}]\end{array}$ & $\begin{array}{c}\text { CAR-T } \\
\text { [cells } / \mu \mathrm{L}]\end{array}$ & MRD-PCR \\
\hline 0 & 3 March 2020 & 0 & 50 & 0.47 & 0.23 & $\mathrm{Nd}$ & $<1 \times 10^{-4 *}$ \\
\hline 7 days & 10 March 2020 & 0 & 319 & 1.16 & 0.22 & $\mathrm{Nd}$ & $\mathrm{Nd}$ \\
\hline 13 days & 16 March 2020 & 0 & 367 & 1.2 & 0.3 & $\mathrm{Nd}$ & $\mathrm{Nd}$ \\
\hline 20 days & 23 March 2020 & 0 & 451 & 1.26 & 0.27 & $\mathrm{Nd}$ & $\mathrm{Nd}$ \\
\hline 27 days & 30 March 2020 & 0 & 460 & 1.7 & 0.7 & $\mathrm{Nd}$ & $\mathrm{Nd}$ \\
\hline 1 month & 3 April 2020 & 0 & 369 & 1.27 & 0.63 & $\mathrm{Nd}$ & $4 \times 10^{-5}$ \\
\hline 2 months & 12 May 2020 & 0 & 1,180 & 2.19 & 0.58 & $\mathrm{Nd}$ & $1.2 \times 10^{-5}$ \\
\hline 3 months & 9 June 2020 & 0 & 928 & 1.73 & 0.31 & $\mathrm{Nd}$ & Negative \\
\hline 4 months & 1 July 2020 & 0 & 1,082 & 2.27 & 0.64 & $\mathrm{Nd}$ & $\mathrm{Nd}$ \\
\hline 5 months & 11 August 2020 & 1 & 1,303 & 3.11 & 1.22 & 1.6 & $\mathrm{Nd}$ \\
\hline 5.5 months & 26 August 2020 & 0 & 1,337 & 2.76 & 0.82 & 2.6 & $\mathrm{Nd}$ \\
\hline 6 months & 10 September 2020 & 0 & 1,003 & 3.25 & 1.69 & 1.3 & Negative \\
\hline 7 months & 26 October 2020 & 0 & 1,489 & 3.11 & 1.21 & 1.7 & $\mathrm{Nd}$ \\
\hline 9 months & 7 December 2020 & 0 & 1,716 & 3.42 & 1.08 & 0.2 & $\mathrm{Nd}$ \\
\hline 10 months & 12 January 2021 & 0 & 2,025 & 3.61 & 0.82 & 1.2 & Negative \\
\hline
\end{tabular}

*Bone marrow evaluation performed before lymphodepleting chemotherapy on 20 February 2020; ANC - absolute neutrophil count; nd - not done

father) was performed. A third relapse (isolated marrow) was confirmed eight months later in January 2019 This was treated with another HIB cycle. Unfortunately, minimal residual disease (MRD) was present both after two weeks and at the end of HIB. Considering the high risk of complications and possible resistance to chemotherapy, inotuzumab ozogamicin was used in post-induction treatment. In July 2019, because of the persistent MRD, it was decided to administer blinatumomab. The therapy was complicated with severe neurotoxicity requiring the child's transfer to the intensive care unit. After a month, despite $100 \%$ allogeneic chimerism, minimal residual disease using polymerase chain reaction (MRD-PCR) was still present at the level of $3 \times 10^{-3}$. We decided to perform a stem cell boost from the same haploidentical donor. About $14.38 \times 10^{6}$ in vitro positively selected CD34/kg recipient's body weight cells were transplanted, without previous conditioning and graft-versus-host disease (GvHD) prophylaxis. After the procedure, MRD was still present, forcing the use of three inotuzumab ozogamicin doses. Because of the multiply relapsed and refractory character of the leukemia, we decided to use CAR-T cell immunotherapy as a salvage treatment. Our patient was in a general good condition, sufficient to tolerate the therapy, without central nervous system involvement. BM biopsy carried out on 15 October 2019 presented as follows: BM M1, chimerism $100 \%$ allogeneic, MRD-PCR positive $3.0 \times 10^{-4}$. A single dose of inotuzumab ozogamycin was given on 30 October 2019. Two weeks later, on 12 November, apheresis aimed to collect MNCs including T cells was performed successfully. At the time of apheresis, the patient's WBC and T cells in peripheral blood exceeded minimal requirements $[1.0 \mathrm{G} / \mathrm{L}$ WBC and $0.3 \mathrm{G} / \mathrm{L} \mathrm{T}$ cells]: $5.54 \mathrm{G} / \mathrm{L}$ and $1.835 \mathrm{G} / \mathrm{L}$ respectively. 5.93 $\times 10^{9} \mathrm{~T}$ cells were collected (minimum $1 \times 10^{9} \mathrm{CD}^{+}$cells). As a bridging therapy, the patient received inotuzumab ozogamycin $\left(0.5 \mathrm{mg} / \mathrm{m}^{2}\right)$ on 13 January 2020 .

BM biopsy before lymphodepleting chemotherapy (LDC) was performed on 20 February, revealing: bone marrow M1, chimerism $100 \%$ allogeneic, MRD-PCR positive below $1 \times 10^{-4}$. On four consecutive days, 25-28 February, LDC with cyclophosphamide $2 \times 500 \mathrm{mg} / \mathrm{m}^{2}$ on days $1-2$ and fludarabine $4 \times 30 \mathrm{mg} / \mathrm{m}^{2}$ on days $1-4$ was performed. On 3 March, thawed $2.2 \times 10^{6} \mathrm{CAR}-\mathrm{T}$ cells/kg recipient's body weight (Kymriah ${ }^{\circledR}$, Novartis) were administered to the patient, following an antihistaminic premedication. Levetiracetam was used to prevent seizures. No typical side effects were observed during the hospitalization $[7,8]$. One month post-transplant, a BM biopsy was carried out, revealing: M1 BM, chimerism 100\% allogeneic (both from bone marrow and peripheral blood), MRD positive at $4 \times 10^{-5}$. For the first time since the MRD measurement in the patient's history, his MRD became negative on day +98 post infusion (9 June 2020).

Now, after more than 11 months of infusion, the patient remains MRD-free and requires immunoglobulin (IVIG or $\mathrm{SCIG)} \mathrm{substitution} \mathrm{due} \mathrm{to} \mathrm{most} \mathrm{welcome} \mathrm{prolonged} \mathrm{B-cell}$ aplasia [7]. His CAR-T cells remain present in peripheral blood; however the number has decreased from roughly 2 cells/ $\mu \mathrm{L} 5-7$ months post infusion to $1.2 / \mu \mathrm{L}$ now (Table I).

A low level of MRD before LDC remains a challenge for physicians. In our hands, the maintenance administration 
of inotuzumab ozogamycin proved to be effective before the final treatment.

Considering the patient's medical history, the 11-month follow-up after CAR-T cells infusion allows us to look into the future with hope tempered by caution. The longer his CAR-T cells persist, the more chance he will have of achieving a long-awaited clinical cure.

Ongoing experience with CAR-T cell therapy tells us that this is not merely an example of fascinating bioengineering, but a realistic and promising therapy with an up to $90 \%$ response rate with durable remissions in a population with refractory high-risk disease [7]. Nevertheless, Polish patients still cannot receive reimbursement for this treatment.

The implementation of CAR-T cell therapy in our patient was possible only thanks to the funds raised by the 'Na Ratunek Dzieciom z Choroba Nowotworowa' foundation and siepomaga.pl.

\section{Authors' contributions}

All authors - data collection. KL, PM, KK - analysis, writing and manuscript acceptance.

\section{Conflict of interest}

The authors declare no conflict of interests.

\section{Financial support}

Funds raised by the Na Ratunek Dzieciom z Choroba Nowotworowa foundation and siepomaga.pl.

\section{Ethics}

The work described in this article has been carried out in accordance with The Code of Ethics of the World Medical Association (Declaration of Helsinki) for experiments involving humans; EU Directive 2010/63/EU for animal experiments; Uniform requirements for manuscripts submitted to biomedical journals.

\section{References}

1. Maude SL, Laetsch TW, Buechner J, et al. Tisagenlecleucel in children and young adults with B-cell lymphoblastic leukemia. N Engl J Med. 2018; 378(5): 439-448, doi: 10.1056/NEJMoa1709866, indexed in Pubmed: 29385370.

2. Cope $\mathrm{S}$, Ayers $\mathrm{D}$, Zhang J, et al. Integrating expert opinion with clinical trial data to extrapolate long-term survival: a case study of CAR-T therapy for children and young adults with relapsed or refractory acute lymphoblastic leukemia. BMC Med Res Methodol. 2019; 19(1): 182, doi: 10.1186/s12874-019-0823-8, indexed in Pubmed: 31477025.

3. Diorio C, Maude SL. CAR T cells vs allogeneic HSCT for poor-risk ALL. Hematology Am Soc Hematol Educ Program. 2020; 2020(1): 501-507, doi: 10.1182/hematology.2020000172, indexed in Pubmed: 33275706.

4. Styczyński J. Where dreams come true: CAR-T cell therapy in Poland! Acta Haematol Pol. 2020; 51(1): 1, doi: 10.2478/ahp-20200001.

5. Dytfeld D, Łojko-Dankowska A, Matuszak M, et al. Road to clinical implementation of CAR-T technology in Poznań. Acta Haematol Pol. 2020; 51(1): 24-28, doi: 10.2478/ahp-2020-0006.

6. Styczyński J. A brief history of CAR-T cells: from laboratory to the bedside. Acta Haematol Pol. 2020; 51(1): 2-5, doi: 10.2478/ahp-2020-0002.

7. Gil L, Łojko-Dankowska A, Matuszak M, et al. CAR-T cell therapy - toxicity and its management. Acta Haematol Pol. 2020; 51(1): 6-10, doi: 10.2478/ahp-2020-0003.

8. Styczyński J. Infections following CAR-T cells therapy: current state-of-the-art review and recommendations. Acta Haematol Pol. 2020; 51(1): 11-16, doi: 10.2478/ahp-2020-0004. 